\title{
NATURAL ANTIMICROBIALS IN THE PIPELINE AND POSSIBLE SYNERGISM WITH ANTIBIOTICS TO OVERCOME MICROBIAL RESISTANCE
}

\author{
EMTENAN M HANAFI ${ }^{1 *}$, ENAS N DANIAL ${ }^{2,3}$ \\ ${ }^{1}$ Department of Animal Reproduction and Artificial Insemination, NRC, Dokki, Giza, Egypt. ${ }^{2}$ Department of Chemistry of Natural and \\ Microbial Products Department, NRC, Dokki, Giza, Egypt. ${ }^{3}$ Department of Applied Biochemistry, Faculty of Science, Jeddah University, \\ Jeddah, Saudi Arabia Arabia. Email: emtenan_28862@hotmail.com
}

Received: 14 December 2018, Revised and Accepted: 11 March 2019

ABSTRACT

The unresponsive use of antibiotics led to the appearance of multiple drug-resistant bacteria strains. Studying the mechanism by which bacteria can resist antibiotics, the so called quorum sensing and biofilm formation, enabled the researchers to find bioactive compounds, derived from eukaryotes and prokaryotes. The disrupt of this mechanism is called quorum sensing inhibitors or quorum quenchers. This article provides an overview on the current research done on such bioactive compounds, the possible use of them as antibiotic alternatives, what are the advantage and disadvantages, the source from which it has been extracted, and how it may succeed to overcome bacterial resistance. The recommendation of researchers is to use some of these natural antimicrobial compounds combined to lower doses of antibiotics for treatment, the fastest way to limit the adverse effects of the exploitation of antibiotics and to avoid bacterial resistance.

Keywords: Bacterial resistance, Antibiotic adjuvants, Antimicrobial enzymes, Antimicrobial peptides, Essential oils, Phytobiotic.

(c) 2019 The Authors. Published by Innovare Academic Sciences Pvt Ltd. This is an open access article under the CC BY license (http://creativecommons. org/licenses/by/4. 0/) DOI: http://dx.doi.org/10.22159/ajpcr.2019.v12i4.30926

\section{INTRODUCTION}

The innovation of antibiotics solved many health problems to human beings and animals from plenty of life-terrifying diseases [1]. The excessive irresponsible use of antibiotics, for human and veterinary therapy, resulted in the appearance of several bacterial strains resistant to antibiotics [2]. Plenty of research work was done to find alternative approaches to control these resistant organisms and the high mortality caused by them [3]. It is worthy to mention that bacterial infections cause approximately $65 \%$ of the total sum of infectious diseases. Bacterial communities produce pheromones or autoinducers act as cell-to-cell signaling to monitor population density and to coordinate the activities of the population such as biofilm formation, virulence, multiplication, spore formation, and horizontal gene transfer. This process is called bacterial quorum sensing [4]. Inside the biofilm, bacteria are more resistant to antibiotics around 1000 times more than their planktonic ones $[5,6]$. Research work done to interfere biofilm formation has enabled us to identify some compounds derived from eukaryotes and prokaryotes with the ability to quench or inhibit the quorum sensing system, called as quorum quenchers (QQ) or quorum sensing inhibitors (QSIs) [7-9]. These compounds gave a chance to develop new drugs to kill pathogens $[10,11]$. The objective of this work is screening of some QSIs and their possible applications as antimicrobial agents aiming to overcome antibiotic resistance and prolong the effective life span of antibiotic.

\section{DEVELOPMENT OF ANTIBIOTIC RESISTANCE AND HEALTH THREATS}

The development of several drug-resistant pathogens was listed by the World Health Organization as one of the top threats to public health in the world [12]. It was anticipated to evolve the bacterial resistance to antibiotic within 50 years approximately after its first use [13]. Unexpectedly, resistance to some antibiotics such as tetracyclines started to develop within a year of its approval by drug FDA [14].

Methicillin was discovered in 1959 and introduced to treat penicillinresistant Staphylococcus aureus, and then, methicillin-resistant phenotype strains were isolated 2 years later [15]. Similarly, the aminoglycoside streptomycin, which inhibits bacterial protein synthesis was introduced for the treatment of tuberculosis in 1945, but the emergence of rRNA mutations conferring streptomycin resistance to Mycobacterium tuberculosis strains was soon reported in 1956 (Table 1).

\section{MECHANISMS BY WHICH BACTERIA RESIST ANTIBIOTICS}

Antibiotic resistance takes place in bacteria by either innate resistance [17] or acquired resistance through gene transfer from adjacent organism [18-20] or increased mutation rates [21-23] or adaptive environmentally induced resistance [24].

Bacterial enzymatic modification leads to inactivation of the antibiotic (this happens to streptomycin which is chemically modified and become no longer able to bind to the ribosome to block protein synthesis) [25-27]. Furthermore, bacteria carry out alteration of the antibiotic target by degrading enzyme (like beta-lactamase proteins, formed by bacteria, might cut beta-lactam ring of the penicillin atom) [28].

In the same time, bacteria can change its cell wall permeability to push the antibiotic outside the cell [29-31].

The infectious disease society of America highlighted S. aureus, Enterococcus faecium, Klebsiella pneumoniae, Pseudomonas aeruginosa, Acinetobacter baumannii, and Enterobacter (ESKAPE) as species capable of "escaping" the antibacterial action of antibiotics by the abovementioned mechanisms. These species constitute a new paradigm in virulence, transmission, and antimicrobial resistance [32].

\section{QUORUM SENSING}

It is the language by which bacterial cell-to-cell communication takes place. It connects different bacterial cells of the same or different species as well as bacteria and the eukaryotic host cell. With the increased bacterial cell number, the production of signals, called autoinducers, grows and reaches a threshold level, whereas a wide alteration in gene expression takes place including genes encoding for adhesins, 
Table 1: History of The Development of Antibiotic Resistance [16]

\begin{tabular}{lll}
\hline Years & Developed & Showed bacterial resistance \\
\hline Before 1935 & Sulfonamides & Sulfonamides \\
$1941-1945$ & B-lactam (penicillin)-streptomycin & B-lactam (penicillin) \\
$1946-1950$ & Chloramphenicol-tetracycline colistin & Tetracycline \\
$1951-1955$ & Erythromycin & Streptomycin-chloramphenicol \\
$1956-1960$ & Vancomycin & colistin \\
$1961-1965$ & Cephalosporins-quinolones & Cephalosporins and quinolones \\
$1966-1970$ & & Erythromycin-vancomycin \\
$1986-1990$ & Oxazolidinones (linezolid) & Oxazolidinones (linezolid) \\
$2001-2005$ & &
\end{tabular}

exopolysaccharides (a major component of the biofilms), and virulent factors production. This gives the bacteria a chance to achieve specific actions that occur only when living in a community not when has been sporadic so that quorum sensing controls production and development of biofilms, virulence factors, sporulation, bioluminescence, and conjugation [33].

Biofilm and virulence disruption agents are called QQ or QSIs. They are considered a feasible alternative to antibiotics [34]

Three approaches were investigated to inhibit microbial QS:

First, disruption of autoinducer synthesis; second, the inhibition of ligand/receptor interactions; and third, degradation of the autoinducer through enzymatic destruction [35].

\section{ADDRESSING ANTIBIOTIC RESISTANCE}

A combination of antimicrobials may give synergistic effect due to the diversity of mechanisms which is necessary to overcome recurrent bacterial communication and kill persisting cells [36]. These multidrug cocktails were not confined to antibiotics but extended to combinations of antibiotics with natural compounds that have the ability of $\mathrm{QQ}$ and act as non-antibiotic adjuvants.

This combination usage promotes the antimicrobial effect and prevents the bacterial resistance because the disruption of biofilm makes bacteria more disposed to even low doses of antibiotics [37]. The synergism between antibiotics and QSIs showed good results in regulating the resistant strains of Staphylococcus pathogenesis, where the bacterial sensitivity to the commercial antibiotics was elevated by RNAIIIinhibiting peptide $[38,39]$. QSIs such as furanone c30, patulin, penicillic acid, and garlic extract have been reported to improve the sensitivity of $P$. aeruginosa to tobramycin and leukocyte phagocytosis $[40,41]$. Intensive research work was done to study such natural antimicrobial compounds that may be used as adjuvants to antibiotics.

\section{SCREENING OF SOME NATURAL ANTIMICROBIAL AGENTS}

\section{Enzymes}

More than 2000 different enzymes are currently known. They are produced by pancreatic ribonuclease and regulated by hormone-sensitive lipase.

Enzymes were grouped into six classes known as oxidoreductase, transferases, hydrolases, lyases (synthases), isomerases, and ligases.

At present, there are several commercial hydrolase preparations, effective against microbial biofilm, such as Spezyme GA300, Pandion, Resinase A2X, and Paradigm. The substrates for the hydrolases are peptidoglycan, the cell wall component which is responsible for the bacterial cell wall rigidity. Degradation of the cell wall leads to cell lyses due to disturbed osmotic pressure inside the cell. Gram-negative bacteria are less sensitive to bacteriolytic enzymes than Gram-positive bacteria due to differences in the cell wall structure.
Proteases are protein hydrolyzing enzymes, out of which subtilisins that are used widely for the control of biofilm in industry [42]. Lysostaphin is a metalloendopeptidase hydrolyzing enzyme. It cleaves Staphylococci cell walls including methicillin-resistant $S$. aureus (MRSA) [43]. Administration of lysostaphin in combination with oxacillin or vancomycin enhanced the antimicrobial effect against MRSA [44].

Among the polysaccharide hydrolyzing enzymes; lysozymes, alginate lysases, Dispersin B and amylases were reported. Lysozyme immobilized in chitosan was effective in inhibiting food spoilage microorganisms [45].

Alpha-amylase hydrolyzes existing biofilms of $S$. aureus [46]. Combination of proteases and amylases was effective in removing a Pseudomonas fluorescens biofilm [47].

The peroxidases, such as lactoperoxidases and myeloperoxidases, use the $\mathrm{H}_{2} \mathrm{O}_{2}$ to oxidize halides (bromide, chlorine, and iodine) and isocyanate producing more potent antimicrobial compounds active against invading pathogens [48].

\section{Antimicrobial Enzymes Derived from Bacteria}

Quorum quenching enzymes that have an ability to degrade QS signal acylated homoserine lactone (AHL) autoinducers are AHL-lactonases, AHL-acylase, decarboxylases, and deaminase [9]. These enzymes were derived from different kinds of bacteria such as Actinobacteria, Rhodococcus, Arthrobacter, Streptomyces, Firmicutes, Bacillus, Oceanobacillus, Anabaena, Cyanobacteria, Proteobacteria, Alteromonas, Comamonas, Halomonas, Hyphomonas, P. aeruginosa, K. pneumoniae, Ralstonia, and Stappia [49-52]. The mentioned organisms have either AHL-acylase or -lactonase enzymes while Rhodococcus erythropolis might be the only organism which has both enzymes [53,54]. Interestingly, Bacillus thuringiensis does not produce the QS signal AHL but produce AHL-lactonase [55]. Microorganisms that produce bacteriolytic enzymes (e.g., streptomycetes) usually express a complex of several cell wall degrading enzymes with different specificities.

Lipase enzymes are considered an innovative and environmentally friendly approach for biofilm control due to their lytic and dispersal activities. Most of lipase enzymes used in industries are of microbial origin. It catalyzes the hydrolysis of esters for long chain aliphatic acids; several microorganisms produce lipases such as eukarya, fungi, actinomycetes, yeast, bacteria, and archaea. Bacterial lipases include Bacillus, Penicillium, Staphylococcus, Pseudomonas, and Aspergillus [56]. $\alpha$-amylase, $\beta$-glucanase, lipase, and protease were examined to disrupt flow-generated biofilms of P. fluorescens. The four enzymes showed modest reduction of biofilm colony-forming units [57].

\section{Antimicrobial Enzymes Derived from Bacteriophage}

Bacteriophages are viruses that replicate inside infected bacteria and then secret endolysins, called lytic system, to weaken the bacterial cell wall resulting in bacterial lysis to come out and spread to infect other bacterial cells. Endolysins, such as glucosidase, endopeptidase, amidase, 
and transglycosylase, showed bacteriolytic activity against Listeria monocytogenes, Bacillus anthracis, Staphylococcus, and Clostridium butyricum [4]. Furthermore, they can clear some Gram-positive bacterial infections such as Enterococcus faecalis and Clostridium perfringens, [58]. The pairing of an antibiotic with a bacteriophage adjuvant is currently used and available in Georgia. Combination of ciprofloxacin and a lytic phage cocktail is currently produced, by PhagoBioDerm, in a biodegradable polymer matrix. Amidase PAL and endopeptidase Cpl1 from phage Cpl1 are synergistically capable to control the systemic pneumococcal disease [59,60]. Endolysins separated from phage phi3626 can treat Clostridium contaminations [61]. The type PAL of endolysin can kill the Streptococcus Group A. The type LYSK endolysins kill Staphylococcus, especially methicillin safe S. aureus [62]. Endolysins PlyV12 demonstrates a decent lytic movement against vancomycin, safe E. faecium, Enterococci, and E. faecalis [63].

\section{Antimicrobial Enzymes Derived from Animal}

Quorum quenching enzymes have been isolated from animals such as rats, mice, and zebrafish.

Porcine kidney acylase I inactivated QS signals and prevented the formation of biofilm in Pseudomonas putida and Aeromonas hydrophila [64]. Mammalian paraoxonases have hydrolytic effect on esters and lactones [65]. Mammalian type of lactonases differs from that derived from bacteria as the first type needs calcium ion to be active [65]. Epithelial cells of human have the ability to inactivate the autoinducer, AHLs, synthesized by P. aeruginosa [66]

Foods such as chicken breast, turkey patties, beef steak, beef patties, and homemade cheeses revealed inhibition for the Gram-positive bacteria autoinducer (AI-2) activity by $84.4-99.8 \%$ [67]. These QSIs vary in their effect on the expression of virulence-related genes [68].

Pancreatic lipase enzymes catalyze fatty acid synthesis in bacteria; therefore, it can serve as a potential antibacterial agent that is effective against many bacterial strains [69]. Lactonase, AHL acylase, and oxidoreductases are from mammalian paraoxonase. They are QSIs and can modulate $P$. aeruginosa infection [70].

\section{Antimicrobial Enzymes Derived from Plants}

Laccases, are QSIs enzymes, have been found in plant extracts derived from fruit, flowers, leaves, and bark of Laurus nobilis, Combretum albiflorum, and Sonchus oleraceus [71,72]. Alliinase and thiol enzyme group separated from garlic and other medicinal plants act as QSIs [73,74], lactonase presents in clover, lotus, legumes, peas, yam beans, and alfalfa showed AHL degrading abilities [75,76]. Papaya (Carica papaya L.) is rich in cysteine protease enzyme which has a crucial role in many vital antimicrobial processes in living organisms [77]

\section{Quorum Quenching Enzymes Derived from Marine Organisms}

Algae like Laminaria digitata has bromoperoxidase enzyme that has QQ ability by oxidation process to AHL signal group (30C $\mathrm{HSL}_{6}$ [78]. Delisea pulchra contain halogenated furanones which similar in shape to bacterial AHLs and can block the receptors (LuxR) and hinder QS process $[79,80]$

Alginate lyases are enzymes, found in algae, invertebrates, and marine microorganisms, used in combination with gentamicin to control $P$. aeruginosa in the respiratory tracts of patients with cystic fibrosis [81-83].

\section{Antimicrobial Digestive Enzymes}

Digestive enzymes supplemented to improve the feed efficiency ratio and stimulate the absorption of nutrients, also affect on the bacterial population in the alimentary tract [84]. Some of these enzymes such as carbohydrates and phytases were synthesized and are commercially sold as feed additives to monogastric animal [85]. These enzymes will affect on the nourishment of intestinal flora which will compete the other pathogenic or harmful types of bacteria [84]. Furthermore, when xylanase and lysozyme enzymes were added to broiler chicken diet, it minimized the gastrointestinal lesions of $C$. perfringens in the ilium $[86,87]$.

In conclusion, combination of certain types of enzymes, polysaccharidedegrading enzymes, DNases, proteases, and anti-quorum sensing enzymes, is required for successful control of microbial infection. Unfortunately, industrial enzyme production is somewhat expensive, especially for biomedical applications where pure enzymes are required [88].

\section{ANTIMICROBIAL PEPTIDES (AMPs)}

AMPs are found among all living organisms as a component of the innate immune response $[90,89]$. Most of the reported AMPs were of animal origin such as glycine/arginine-rich peptides, tachyplesin, brevinin peptides, and alpha- and beta-defensins [91]. In plants, few AMPs have been isolated from seeds, roots, stems, flowers, and leaves from various species and have demonstrated activities against different pathogens such as viruses, fungi, bacteria, protozoa, and parasites. Thionins, defensins, lipid transfer proteins, puroindolines, and snakins were different groups of AMPs reported in plants [92]. >880 different AMPs with the same biological activity to the naturally occurring AMPs have been designed and engineered from natural nucleic acid sequences [93] or selected from online combinatorial libraries [94].

Bacterial resistance against AMPs is apparently more difficult to be emerged in comparison with existing antibiotics as they have several targets and several modes of actions [95]. However, some bacteria developed resistance against human AMPs during evolution [96,97]. Hence, plant AMPs could be better than human ones because they rarely contact human pathogens to induce such resistance.

AMPs range from 4 to about 40 amino acids in length, engineered AMPs are identical to natural ones and all of them are hydrophobic and cationic in nature. It plays its role inducing changes in membrane permeabilization, destabilization, inhibition of macromolecules synthesis, intracellular translocation of the peptide, and inhibition of DNA/RNA/protein synthesis [98]. As polycationic peptides, AMPs interact electrostatically with negatively charged bacterial surface structures including lipoteichoic acids, and then, they interact with the lipid bilayers of the cytoplasmic membrane forming transmembrane pores and resulting in weakening of the membrane [99]. AMPs exert its effect on microbial plasma membranes, within few seconds of addition. Then after, within $1 \mathrm{~h}$, bacterial membrane vesiculation, fragmentation release of DNA, cell aggregation, and destruction of cell morphology were noted. Thus, AMPs should rapidly pass through outer membrane thick proteoglycan layer of Gram-positive bacteria and the lipopolysaccharide layer of Gram-negative bacteria [100].

It is apparent not always biomembrane permeabilization is required for AMPs activity as it can translocate inside microbial membranes as well. This translocation results in membrane leakage and may occur at low concentrations of AMP before inducing permeabilization. For example, both the defensin cryptdin- 4 of human and the AMP magainin 2 of frog translocate across bacterial cell wall bilayers within average $10 \min [101,102]$

\section{AMPs Derived from Bacteria}

The bacterial enzymes peptide synthetases produce the AMPs such as polymyxin, gramicidin, bacteriocin, and sugar peptide. The polypeptide polymexin is obtained from Bacillus polymyxa. It is effective against different pathogenic bacterial species such as P. aeruginosa, Salmonella, Escherichia coli, and K. pneumoniae. The polypeptide bacteriocin is effective against Gram-negative cocci and spirochetes. Bacteriocin has been used commercially as feed additive for animals combined with bacitracin methylene salicylic acid and zinc [103]. There are several products of bacteriocins such as nisin, fermenticin, subticin, plantacin, helveticin, lactacin, and sakacin that have antimicrobial effect against resistant pathogenic strains [104], bacteriocin can kill bacterial cell by interfering its protein metabolism on molecular bases. 
Many bacteriocins are applied as bacteriostatic in food products [105] as it can inhibit foodborne pathogens such as Clostridium botulinum, S. aureus, Bacillus spp., L. monocytogenes, and E. faecalis $[106,107]$.

\section{AMPs derived from plants}

Major AMPs reported in plants were 5-13 kDa. Such small AMPs were shown to demonstrate good antibacterial activity against some bacteria such as $S$. aureus, E. coli, K. pneumoniae, and P. aeruginosa. Plant AMPs like other AMPs have higher activity against Gram-positive than Gramnegative bacteria [108-110]. Different kinds of antimicrobial substances were reported such as saponins [111], canavanine, and some important antifungal defensins [112]. Antimicrobial activity of AMPs obtained from wheat endosperm was reported against S. aureus and Micrococcus luteus [113]; other studies showed that extracts of AMPs from different germinating and ungerminated seeds of Pisum sativum, Punica granatum, Cocos nucifera L., and Phaseolus vulgaris showed broad spectrum of antibacterial activity against Micrococcus luteus, S. aureus, Staphylococcus epidermidis, Salmonella typhi, K. pneumoniae, E. coli, Proteus vulgaris, Pasteurella multocida, and P. aeruginosa [114].

\section{AMPs derived from marine organism}

Marine green growth is rich in peptides and high assorted proteins [115]. Crypteins, the recently produced peptides, have novel therapeutic effect $[116,117]$. Brown seaweed Saccharina longicruris is rich in AMPs ( $>10 \mathrm{kDa} \mathrm{MW}$ ) resulting from trypsin enzymatic hydrolysis and extracted using HPLC. Other subfractions of peptide precursors were identified such as ubiquitin, leucine, and histone that play a part of the innate immune defense of the seaweed [118].

\section{PLANT EXTRACT \& ESSENTIAL OILS (EOS)}

Plant materials, known as phytobiotics, have been introduced in animal nutrition as antioxidative, antimicrobial, anti-inflammatory, and antiparasitic factors $[119,120]$. The phytobiotic compounds were classified into phenolics/polyphenols, alkaloids, terpenoids/EOs, and lectins/polypeptides [121]. Plant extracts exert the antimicrobial effect at MIC $100 \sim 1000 \mu \mathrm{g} / \mathrm{ml}$ in vitro [122]. These phytobiotics have different modes of action against pathogens. First, tannins act by iron deprivation and enzymes interactions [123]. Second, cryptolepine may act as DNA intercalator and an inhibitor of topoisomerase enzyme [124]. Third, saponins act on the bacterial membrane by binding with sterols causing membrane damages and deformity of cells [125]. In the same time, some plant compounds act as QSI as their chemical structure is like those of AHL so it can bind its receptors (LuxR/LasR) [126]. Furthermore, degradation of AHL signal takes place under the effect of $\gamma$-aminobutyric acid which promotes the bacteriolytic enzyme, lactonase [127]. Flavonoids such as kaempferol, naringenin, quercetin, and apigenin work as QSIs by inhibition of the QS autoinducers, HAI-1 or AI-2, mediated bioluminescence in Vibrio harveyi [128]. Catechins produced by herbal plants like tea can stimulate AHL-lactonase and clear the plasmid of E. coli [129]. Furocoumarins and rosmarinic acid present in grapefruit juice and the roots of sweet basil corrupt the biofilm formation by E. coli and $P$. aeruginosa, respectively $[130,131]$. Thymol is currently used in combination with vancomycin and EDTA as antimicrobial [132]. Furthermore, the combined effect of the antibiotic, tobramycin, and some plant extracts (cinnamaldehyde and baicalin hydrate as QSI) was effective to clear the infected lungs with Burkholderia cenocepacia and P. aeruginosa [133-135]. The usage of EO to combat epidemic infection by multiresistant bacteria is promising. The EO of lemon, thyme white, cinnamon, and lemongrass showed high antibacterial effect against some problematic strains such as Streptococcus, MRSA, and Candida strains [136,137]. The synergistic effect between the EO and antibiotics was reported where Mentha piperita, Thymus vulgaris, and Rosmarinus officinalis oils when combined with ciprofloxacin showed more efficient antimicrobial effect [138]. Hydrophobicity of EOs is the main reason of increased bacterial cell permeability and consequent leakage of cell constituents [139]. followed by disturbance of vital functions such as nutrient processing, synthesis of structural macromolecules, secretion of many growth key enzymes and protein synthesis. E0 disrupts and lowers the intracellular PH of bacteria and consequently impairs many crucial cellular processes such as DNA transcription, protein synthesis, and enzymatic activity [140]. Furthermore, the production of ATP in prokaryotes occurs both in the cell wall and in the cytosol by glycolysis. Hence, the alterations on intracellular and external ATP balance will be affected due to the action of the EO on the cell membrane [141].

The anti-QS activity of EOs or its components was reported as they affect on the autoinducer expression [142].

\section{CONCLUSION \& RECOMMENDATION}

We have to put in mind that alternatives to antibiotics should be nontoxic, easily excreted from the body and have low residues, not stimulate bacterial resistance, be stable and do not decompose inside GIT, do not cause environmental pollution, have good taste, and kill the pathogen without destroying the normal flora.

Actually, till present, there is no antibiotic alternative that meets all the above-mentioned criteria. All proteinaceous compounds, such as feed enzymes and AMPs that have been put into market as well as bacteriophage lysins, enzymatic biofilm inhibitors, and quorum quenching enzymes under development, are naturally unstable and easily degraded in the digestive tract. On the other hand, antibiotics can directly kill bacteria or inhibit with better antibacterial effect than all antibiotic replacements. Antibiotics are made by single and relatively pure active ingredient with consistency, high stability, and quality ensured by good manufacturing practice. However, researchers appreciate the combination of more than antimicrobial compound to avoid the development of bacterial resistance. Combination of biofilm inhibitors with antibiotics showed good results than when used sporadic. Hence, we have to put in mind that we have to use the natural antimicrobials to prevent than to cure disease or in combination to antibiotics as adjuvant to improve its function and waiting for updates from scientific research.

\section{AUTHORS' CONTRIBUTIONS}

Emtenan Mohamed is specialized in veterinary medicine and her area of interest is to find natural product that may improve animal health and decrease the risk of disease. Enas is specialized in enzymology. Hence, both authors shared in throwing light on most antimicrobial products and the last updates in this respect. Editing and scientific revision were done by Emtenan.

\section{CONFLICTS OF INTEREST STATEMENT}

Authors declared that there is no competing interest between them.

\section{REFERENCES}

1. Kalia VC, Rani A, Lal S, Cheema S, Raut CP. Combing databases reveals potential antibiotic producers. Expert Opin Drug Discov 2007; 2:211-24.

2. Rasmussen TB, Skindersoe ME, Bjarnsholt T, Phipps RK, Christensen KB, Jensen PO. Identity and effects of quorumsensing inhibitors produced by Penicillium species. Microbiology 2005;151:1325-40.

3. Bjarnsholt T, Jensen PØ, Burmølle M, Hentzer M, Haagensen JA, Hougen HP. Pseudomonas aeruginosa tolerance to tobramycin, hydrogen peroxide and polymorphonuclear leukocytes is quorumsensing dependent. Microbiology 2005;151:373-83.

4. Low LY, Yang C, Perego M, Osterman A, Liddington RC. Structure and lytic activity of a Bacillus anthracis prophage endolysin. J Biol Chem 2005;280:35433-9.

5. Koch C, Høiby N. Diagnosis and treatment of cystic fibrosis. Respiration 2000;67:239-47.

6. Olsen JA, Severinsen R, Rasmussen TB, Hentzer M, Givskov M, Nielsen J. Synthesis of new 3- and 4-substituted analogues of acyl homoserine lactone quorum sensing autoinducers. Bioorg Med Chem Lett 2002;12:325-8.

7. Huma N, Shankar P, Kushwah J, Bhushan A, Joshi J, Mukherjee T. 
Diversity and polymorphism in AHL-lactonase gene (aiiA) of Bacillus. J Microbiol Biotechnol 2011:21:1001-11.

8. Jamuna Bai A, Rai VR. Bacterial quorum sensing and food industry. Compr Rev Food Sci Food Saf 2011;10:184-94

9. Kalia VC, Purohit HJ. Quenching the quorum sensing system: Potential antibacterial drug targets. Crit Rev Microbiol 2011;37:121-40.

10. Drenkard E. Antimicrobial resistance of Pseudomonas aeruginosa biofilms. Microbes Infect 2003;5:1213-9.

11. Zeng Z, Qian L, Cao L, Tan H, Huang Y, Xue X. Virtual screening for novel quorum sensing inhibitors to eradicate biofilm formation of Pseudomonas aeruginosa. Appl Microbiol Biotechnol 2008;79: 119-26.

12. Bassetti M, Ginocchio F, Mikulska M. New treatment options against gram-negative organisms. Crit Care 2011;15:215.

13. Bhatt D, Kavitha M, Nisha CK, Mahajan Y. Nanotechnology solutions to combat Superbugs, Nanowerk; 2013. Available from: http://www. nanowerk.com/spotlight/spotid=32188.php

14. Hu Y, Shamaei-Tousi A, Liu Y, Coates A. A new approach for the discovery of antibiotics by targeting non-multiplying bacteria: A novel topical antibiotic for staphylococcal infections. PLoS One 2010;5:e11818

15. Enright MC, Robinson DA, Randle G, Feil EJ, Grundmann H, Spratt BG, et al. The evolutionary history of methicillin-resistant Staphylococcus aureus (MRSA). Proc Natl Acad Sci U S A 2002;99:7687-92.

16. Springer B, Kidan YG, Prammananan T, Ellrott K, Böttger EC, Sander P, et al. Mechanisms of streptomycin resistance: Selection of mutations in the $16 \mathrm{~S}$ rRNA gene conferring resistance. Antimicrob Agents Chemother 2001;45:2877-84.

17. Vranakis I, Goniotakis I, Psaroulaki A, Sandalakis V, Tselentis Y, Gevaert K. Proteome studies of bacterial antibiotic resistance mechanisms. J Proteomics 2014;97:88-99.

18. Kester JC, Fortune SM. Persisters and beyond: Mechanisms of phenotypic drug resistance and drug tolerance in bacteria. Crit Rev Biochem Mol Biol 2014;49:91-101.

19. Woo PC, To AP, Lau SK, Yuen KY. Facilitation of horizontal transfer of antimicrobial resistance by transformation of antibiotic-induced cell-wall-deficient bacteria. Med Hypotheses 2003;61:503-8.

20. Norman A, Hansen LH, Sørensen SJ. Conjugative plasmids: Vessels of the communal gene pool. Philos Trans R Soc Lond B Biol Sci 2009; $364: 2275-89$

21. Martinez JL, Baquero F. Mutation frequencies and antibiotic resistance. Antimicrob Agents Chemother 2000;44:1771-7.

22. Cirz RT, Chin JK, Andes DR, de Crécy-Lagard V, Craig WA, Romesberg FE. Inhibition of mutation and combating the evolution of antibiotic resistance. PLoS Biol 2005;3:e176.

23. Kohanski MA, DePristo MA, Collins JJ. Sublethal antibiotic treatment leads to multidrug resistance via radical-induced mutagenesis. Mol Cell 2010;37:311-20.

24. Sánchez-Romero MA, Casadesús J. Contribution of phenotypic heterogeneity to adaptive antibiotic resistance. Proc Natl Acad Sci U S A 2014;111:355-60.

25. Wright GD. Bacterial resistance to antibiotics: Enzymatic degradation and modification. Adv Drug Deliv Rev 2005;57:1451-70.

26. Ramirez MS, Tolmasky ME. Aminoglycoside modifying enzymes. Drug Resist Updat 2010;13:151-71.

27. Tillotson GS, Theriault N. New and alternative approaches to tackling antibiotic resistance. F1000Prime Rep 2013;5:51.

28. Wilson DN. Ribosome-targeting antibiotics and mechanisms of bacterial resistance. Nat Rev Microbiol 2014;12:35-48.

29. Li XZ, Nikaido H. Efflux-mediated drug resistance in bacteria: An update. Drugs 2009;69:1555-623.

30. Poole K, Russell A, Lambert P. Mechanisms of antimicrobial resistance: opportunities for new targeted therapies. Adv Drug Deliv Rev 2005;57:1443-5.

31. Alekshun MN, Levy SB. Molecular mechanisms of antibacterial multidrug resistance. Cell 2007;128:1037-50.

32. Boucher HW, Talbot GH, Bradley JS, Edwards JE, Gilbert D, Rice LB, et al. Bad bugs, no drugs: No ESKAPE! An update from the infectious diseases society of America. Clin Infect Dis 2009;48:1-2.

33. Miller AA, Miller PF. Emerging Trends in Antibacterial Discovery: Answering the Call to Arms. Norfolk, UK: Caister Academic Press; 2011. Available from: https://www.caister.com/hsp/pdf/flyer/ antibacterial-discovery.pdf

34. Huma N, Shankar P, Kushwah J, Bhushan A, Joshi J, Mukherjee T. Diversity and polymorphism in AHL-lactonase gene (aiiA) of Bacillus. J Microbiol Biotechnol 2011;21:1001-11.
35. Carlier A, Chevrot R, Dessaux Y, Faure D. The assimilation of gamma-butyrolactone in Agrobacterium tumefaciens C58 interferes with the accumulation of the $\mathrm{N}$-acyl-homoserine lactone signal. Mol Plant Microbe Interact 2004:17:951-7.

36. Fan X, Bai L, Zhu L, Yang L, Zhang X. Marine algae-derived bioactive peptides for human nutrition and health. J Agric Food Chem 2014; 62:9211-22.

37. Markoishvili K, Tsitlanadze G, Katsarava R, Morris JG Jr., Sulakvelidze A. A novel sustained-release matrix based on biodegradable poly (ester amide)s and impregnated with bacteriophages and an antibiotic shows promise in management of infected venous stasis ulcers and other poorly healing wounds. Int J Dermatol 2002;41:453-8.

38. Balaban N, Gov Y, Bitler A, Boelaert JR. Prevention of Staphylococcus aureus biofilm on dialysis catheters and adherence to human cells. Kidney Int 2003;63:340-5.

39. Giacometti A, Cirioni O, Ghiselli R, Dell'Acqua G, Orlando F, D'Amato G. RNAIII-inhibiting peptide improves efficacy of clinically used antibiotics in a murine model of staphylococcal sepsis. Peptides $2005 ; 26: 169-75$.

40. Rasmussen TB, Skindersoe ME, Bjarnsholt T, Phipps RK, Christensen KB, Jensen PO. Identity and effects of quorum-sensing inhibitors produced by Penicillium species. Microbiology 2005;151: 1325-40.

41. Bjarnsholt T, Jensen PØ, Burmølle M, Hentzer M, Haagensen JA, Hougen HP. Pseudomonas aeruginosa tolerance to tobramycin, hydrogen peroxide and polymorphonuclear leukocytes is quorumsensing dependent. Microbiology 2005;151:373-83.

42. Longhi C, Scoarughi GL, Poggiali F, Cellini A, Carpentieri A, Seganti L, et al. Protease treatment affects both invasion ability and biofilm formation in Listeria monocytogenes. Microb Pathog 2008;45:45-52

43. Miao J, Pangule RC, Paskaleva EE, Hwang EE, Kane RS, Linhardt RJ, et al. Lysostaphin-functionalized cellulose fibers with antistaphylococcal activity for wound healing applications. Biomaterials 2011;32:9557-67.

44. Kiri N, Archer G, Climo MW. Combinations of lysostaphin with betalactams are synergistic against Oxacillin-resistant Staphylococcus epidermidis. Antimicrob Agents Chemother 2002:46:2017-20.

45. Lian Z, Ma Z, Wei J, Liu H. Preparation and characterization of immobilized lysozyme and evaluation of its application in edible coatings. Process Biochem 2012;47:201-8.

46. Oulahal-Lagsir N, Martial-Gros A, Bonneau M, Blum LJ. "Escherichia coli-milk" biofilm removal from stainless steel surfaces: Synergism between ultrasonic waves and enzymes. Biofouling 2003; 19:159-68.

47. Leroy C, Delbarre C, Ghillebaert F, Compere C, Combes D. Effects of commercial enzymes on the adhesion of a marine biofilm-forming bacterium. Biofouling 2008;24:11-22.

48. Klaunig JE, Kamendulis LM, Hocevar BA. Oxidative stress and oxidative damage in carcinogenesis. Toxicol Pathol 2010;38:96-109.

49. Romero M, Martin-Cuadrado AB, Otero A. Determination of whether quorum quenching is a common activity in marine bacteria by analysis of cultivable bacteria and metagenomic sequences. Appl Environ Microbiol 2012;78:6345-8

50. Kalia VC, Purohit HJ. Quenching the quorum sensing system: Potential antibacterial drug targets. Crit Rev Microbiol 2011;37:121-40.

51. Dong YH, Zhang LH. Quorum sensing and quorum-quenching enzymes. J Microbiol 2005;43:101-9.

52. Azmi W. Arthrobacter as biofactory of therapeutic enzymes. Int $\mathrm{J}$ Pharm Pharm Sci 2018;11:1.

53. Park SY, Hwang BJ, Shin MH, Kim JA, Kim HK, Lee JK, et al. N-acylhomoserine lactonase producing Rhodococcus spp. with different AHL-degrading activities. FEMS Microbiol Lett 2006;261:102-8.

54. Uroz S, Oger PM, Chapelle E, Adeline MT, Faure D, Dessaux Y. A Rhodococcus qsdA-encoded enzyme defines a novel class of largespectrum quorum-quenching lactonases. Appl Environ Microbiol 2008:74:1357-66.

55. Bentley SD, Chater KF, Cerdeño-Tárraga AM, Challis GL, Thomson NR, James KD. Complete genome sequence of the model actinomycete Streptomyces coelicolor A3(2). Nature 2002;417:141-7.

56. Kumar S, Kikon K, Upadhyay A, Kanwar SS, Gupta R. Production, purification, and characterization of lipase from thermophilic and alkaliphilic Bacillus coagulans BTS-3. Protein Expr Purif 2005;

57. Sharma R, Chisti Y, Banerjee UC. Production, purification, characterization, and applications of lipases. Biotechnol Adv 
2001;19:627-62.

58. Fenton M, Ross P, McAuliffe O, O’Mahony J, Coffey A. Recombinant bacteriophage lysins as antibacterials. Bioeng Bugs 2010;1:9-16.

59. Fischetti VA. Bacteriophage lytic enzymes: Novel anti-infectives. Trends Microbiol 2005;13:491-6.

60. Loeffler JM, Djurkovic S, Fischetti VA. Phage lytic enzyme cpl-1 as a novel antimicrobial for pneumococcal bacteremia. Infect Immun 2003;71:6199-204.

61. Courchesne NM, Parisien A, Lan CQ. Production and application of bacteriophage and bacteriophage-encoded lysins. Recent Pat Biotechnol 2009;3:37-45

62. O'Flaherty S, Ross RP, Coffey A. Bacteriophage and their lysins for elimination of infectious bacteria. FEMS Microbiol Rev 2009;33: 801-19.

63. Zhang HB, Wang C, Zhang LH. The quormone degradation system of Agrobacterium tumefaciens is regulated by starvation signal and stress alarmone (p)ppGpp. Mol Microbiol 2004;52:1389-401.

64. Paul D, Kim YS, Ponnusamy K, Kweon JH. Application of quorum quenching to inhibit biofilm fermentation. Environ Eng Sci 2010;86:1267-79. Available from: https://www.link.springer.com/ article/10.1007/s00253-010-2521-7

65. Teiber JF, Horke S, Haines DC, Chowdhary PK, Xiao J, Kramer GL. Dominant role of paraoxonases in inactivation of the Pseudomonas aeruginosa quorum-sensing signal N-(3-oxododecanoyl)-Lhomoserine lactone. Infect Immun 2008;76:2512-9.

66. Stoltz DA, Ozer EA, Ng CJ, Yu JM, Reddy ST, Lusis AJ. Paraoxonase-2 deficiency enhances Pseudomonas aeruginosa quorum sensing in murine tracheal epithelia. Am J Physiol Lung Cell Mol Physiol 2007; 292:L852-60.

67. Yang F, Wang LH, Wang J, Dong YH, Hu JY, Zhang LH. Quorum quenching enzyme activity is widely conserved in the sera of Mammalian species. FEBS Lett 2005;579:3713-7.

68. Widmer KW, Jesudhasan PR, Dowd SE, Pillai SD. Differential expression of virulence-related genes in A Salmonella enterica serotype typhimurium luxS mutant in response to autoinducer AI-2 and poultry meat-derived AI-2 inhibitor. Foodborne Pathog Dis 2007; $4 \cdot 5-15$

69. Sharma R, Chisti Y, Banerjee UC. Production, purification, characterization, and applications of lipases. Biotechnol Adv 2001; 19:627-62.

70. Ozer EA, Pezzulo A, Shih DM, Chun C, Furlong C, Lusis AJ. Human and murine paraoxonase 1 are host modulators of Pseudomonas aeruginosa quorum-sensing. FEMS Microbiol Lett 2005;253:29-37.

71. Dong $\mathrm{YH}$, Zhang LH. Quorum sensing and quorum-quenching enzymes. J Microbiol 2005;43:101-9.

72. Al-Hussaini R, Mahasneh AM. Microbial growth and quorum sensing antagonist activities of herbal plants extracts. Molecules 2009; 14:3425-35

73. Bjarnsholt T, Jensen PØ, Burmølle M, Hentzer M, Haagensen JA, Hougen HP. Pseudomonas aeruginosa tolerance to tobramycin, hydrogen peroxide and polymorphonuclear leukocytes is quorumsensing dependent. Microbiology 2005;151:373-83.

74. Adonizio A, Kong KF, Mathee K. Inhibition of quorum sensingcontrolled virulence factor production in Pseudomonas aeruginosa by South Florida plant extracts. Antimicrob Agents Chemother 2008;52:198-203.

75. Fatima Q, Zahin M, Khan MS, Ahmad I. Modulation of quorum sensing controlled behaviour of bacteria by growing seedling, seed and seedling extracts of leguminous plants. Indian $\mathrm{J}$ Microbiol 2010;50:238-42.

76. Götz C, Fekete A, Gebefuegi I, Forczek ST, Fuksová K, Li X. Uptake, degradation and chiral discrimination of N-acyl-D/L-homoserine lactones by barley (Hordeum vulgare) and yam bean (Pachyrhizus erosus) plants. Anal Bioanal Chem 2007;389:1447-57.

77. Tsuge H, Nishimura T, Tada Y, Asao T, Turk D, Turk V, et al. Inhibition mechanism of cathepsin L-specific inhibitors based on the crystal structure of papain-CLIK148 complex. Biochem Biophys Res Commun 1999;266:411-6.

78. Borchardt SA, Allain EJ, Michels JJ, Stearns GW, Kelly RF, McCoy WF. Reaction of acylated homoserine lactone bacterial signaling molecules with oxidized halogen antimicrobials. Appl Environ Microbiol 2001;67:3174-9.

79. Manefield M, Harris L, Rice SA, de Nys R, Kjelleberg S. Inhibition of luminescence and virulence in the black tiger prawn (Penaeus monodon) pathogen Vibrio harveyi by intercellular signal antagonists. Appl Environ Microbiol 2000;66:2079-84

80. Ren D, Bedzyk LA, Ye RW, Thomas SM, Wood TK. Differential gene expression shows natural brominated furanones interfere with the autoinducer-2 bacterial signaling system of Escherichia coli. Biotechnol Bioeng 2004;88:630-42.

81. Alkawash MA, Soothill JS, Schiller NL. Alginate lyase enhances antibiotic killing of mucoid Pseudomonas aeruginosa in biofilms. APMIS 2006;114:131-8.

82. Gacesa P. Alginate-modifying enzymes: A proposed unified mechanism of action for the lyases and epimerases. FEBS Lett 1987; 212:199-202

83. Lamppa JW, Ackerman ME, Lai JI, Scanlon TC, Griswold KE. Genetically engineered alginate lyase-PEG conjugates exhibit enhanced catalytic function and reduced immunoreactivity. PLoS One 2011; 6:e17042

84. Bedford MR, Cowieson AJ. Exogenous enzymes and their effects on intestinal microbiology. Anim Feed Sci Technol 2012;173:76-85.

85. Adeola O, Cowieson AJ. Board invited review: opportunities and challenges in using exogenous enzymes to improve no ruminant animal production. J Anim Sci 2011;89:3189-218.

86. Cheng G, Hao H, Xie S, Wang X, Dai M, Huang L, et al. Antibiotic alternatives: The substitution of antibiotics in animal husbandry? Front Microbiol 2014;5:217.

87. Kokare CR, Chakraborty S, Khopade AN, Mahadik KR. Biofilms: Importance and applications. Ind J Biotechnol 2009;8:159-68.

88. Thallinger B, Prasetyo EN, Nyanhongo GS, Guebitz GM. Antimicrobial enzymes: An emerging strategy to fight microbes and microbial biofilms. Biotechnol J 2013;8:97-109.

89. Andrea G, Giovanna P, Silvia FN. Antimicrobial peptides: An overview of a promising class of therapeutics. Central Eur J Biol 2007;2:1-33

90. Atousa A, Rasoul R, Giti E, Fatemeh M, Alireza G. Identification and primary characterization of a plant antimicrobial peptide with remarkable inhibitory effects against antibiotic resistant bacteria. Afr J Biotechnol 2012;11:9672-6.

91. Kamysz W. Are antimicrobial peptides an alternative for conventional antibiotics? Nucl Med Rev Cent East Eur 2005;8:78-86.

92. Nawrot R, Barylski J, Nowicki G, Broniarczyk J, Buchwald W, Goździcka-Józefiak A, et al. Plant antimicrobial peptides. Folia Microbiol (Praha) 2014;59:181-96.

93. Hilpert K, Elliott MR, Volkmer-Engert R, Henklein P, Donini O, Zhou Q, et al. Sequence requirements and an optimization strategy for short antimicrobial peptides. Chem Biol 2006;13:1101-7.

94. Rathinakumar R, Walkenhorst WF, Wimley WC. Broad-spectrum antimicrobial peptides by rational combinatorial design and highthroughput screening: The importance of interfacial activity. J Am Chem Soc 2009;131:7609-17.

95. Hancock RE, Sahl HG. Antimicrobial and host-defense peptides as new anti-infective therapeutic strategies. Nat Biotechnol 2006;24:1551-7.

96. Guilhelmelli F, Vilela N, Albuquerque P, Derengowski Lda S, SilvaPereira I, Kyaw CM, et al. Antibiotic development challenges: The various mechanisms of action of antimicrobial peptides and of bacterial resistance. Front Microbiol 2013;4:353.

97. Peschel A, Sahl HG. The co-evolution of host cationic antimicrobial peptides and microbial resistance. Nat Rev Microbiol 2006;4:529-36.

98. Rios AC, Moutinho CG, Pinto FC, Del Fiol FS, Jozala A, Chaud MV, et al. Alternatives to overcoming bacterial resistances: State-of-theart. Microbiol Res 2016;191:51-80

99. Brogden KA. Antimicrobial peptides: Pore formers or metabolic inhibitors in bacteria? Nat Rev Microbiol 2005;3:238-50.

100. Matsuzaki K, Sugishita K, Harada M, Fujii N, Miyajima K. Interactions of an antimicrobial peptide, magainin 2, with outer and inner membranes of gram-negative bacteria. Biochim Biophys Acta 1997;1327:119-30.

101. Zhang G, Lin X, Long Y, Wang Y, Zhang Y, Mi H, et al. A peptide fragment derived from the T-cell antigen receptor protein alpha-chain adopts beta-sheet structure and shows potent antimicrobial activity. Peptides 2009;30:647-53.

102. Matsuzaki K. Control of cell selectivity of antimicrobial peptides. Biochim Biophys Acta 2009;1788:1687-92

103. Cotter PD, Hill C, Ross RP. Bacteriocins: Developing innate immunity for food. Nat Rev Microbiol 2005;3:777-88

104. Field D, Cotter P, Hill C, Ross RP. Bacteriocin biosynthesis, structure, and function. In: Riley MA, Gillor O, editors. Research and Applications in Bacteriocins. Vol. 4. Amhers, USA: Horizon Bioscience; 2007. p. 5-41.

105. Diep DB, Axelsson L, Grefsli C, Nes IF. The synthesis of the bacteriocin sakacin $\mathrm{A}$ is a temperature-sensitive process regulated by a pheromone peptide through a three-component regulatory system. 
Microbiology 2000;146 (Pt 9):2155-60.

106. Rodríguez JM, Martínez MI, Kok J. Pediocin PA-1, a wide-spectrum bacteriocin from lactic acid bacteria. Crit Rev Food Sci Nutr 2002;42:91-121.

107. Tahiri I, Desbiens M, Benech R, Kheadr E, Lacroix C, Thibault S, et al. Purification, characterization and amino acid sequencing of divergicin M35: A novel class IIa bacteriocin produced by Carnobacterium divergens M35. Int J Food Microbiol 2004;97:123-36.

108. Peschel A, Sahl HG. The co-evolution of host cationic antimicrobial peptides and microbial resistance. Nat Rev Microbiol 2006;4:529-36.

109. Thomma BP, Cammue BP, Thevissen K. Plant defensins. Planta 2002;216:193-202.

110. Portieles R, Ayra C, Borras O. Basic insight on plant defensins. Biotecnol Apl 2006;23:75-8.

111. Avato P, Bucci R, Tava A, Vitali C, Rosato A, Bialy Z, et al. Antimicrobial activity of saponins from Medicago sp.: Structureactivity relationship. Phytother Res 2006;20:454-7.

112. Gao AG, Hakimi SM, Mittanck CA, Wu Y, Woerner BM, Stark DM. Fungal pathogen protection in potato by expression of a plant defensin peptide. Nat Biotechnol 2000;18:1307-10.

113. Kumar DV, Sati OP, Tripathi MK, Kumar A. Isolation, characterization and antimicrobial activity at diverse dilution of wheat puroindoline protein. World J Agric Sci 2009;5:297300. Available from: https://www.pdfs.semanticscholar.org/ a1a0/0551732c823beb0a410abe9627d3c9c3243d.pdf

114. Saima R,Azra K. Isolation and characterization of peptide(s) from Pisum sativum having antimicrobial activity against various bacteria. Pak J Bot 2011;43:2971-8. Available from: https://www.pdfs.semanticscholar. org/5530/e062a38161d084b6b64be8350a59df4bf29d.pdf.

115. $\mathrm{Ng} \mathrm{JH}$, Ilag LL. Cryptic protein fragments as an emerging source of peptide drugs. IDrugs 2006;9:343-6.

116. Fan X, Bai L, Zhu L, Yang L, Zhang X. Marine algae-derived bioactive peptides for human nutrition and health. J Agric Food Chem 2014; 62:9211-22.

117. Nair R, Chabhadiya R, Chanda S. Marine algae: Screening for a potent antibacterial agent. J Herb Pharmacother 2007;7:73-86.

118. Beaulieu L, Bondu S, Doiron K, Rioux LE, Turgeon SL. Characterization of antibacterial activity from protein hydrolysates of the macroalga Saccharina long cruris and identification of peptides implied in bioactivity. J Funct Foods 2015;17:685-97.

119. Vondruskova H, Slamova R, Trckova M, Zraly Z, Pavlik I. Alternatives to antibiotic growth promoters in prevention of diarrhoea in weaned piglets: A review. Vet Med 2010;55:199-224.

120. Hashemi SR, Davoodi H. Herbal plants and their derivatives as growth and health promoters in animal nutrition. Vet Res Commun 2011;35:169-80.

121. Windisch W, Schedle K, Plitzner C, Kroismayr A. Use of phytogenic products as feed additives for swine and poultry. J Anim Sci 2008;86:E140-8.

122. Simões M, Bennett RN, Rosa EA. Understanding antimicrobial activities of phytochemicals against multidrug resistant bacteria and biofilms. Nat Prod Rep 2009;26:746-57.

123. Scalbert A. Antimicrobial properties of tannins. Phytochemistry 1991; 30:3875-83.

124. Karou D, Savadogo A, Canini A, Yameogo S, Montesano C, Simpore J. Antibacterial activity of alkaloids from Sida acuta. Afr J Biotechnol 2005;4:1452-7. Available from: http://www.cerbafaso.org/textes/ publications/34ph alkalo.pdf.

125. Morrissey JP, Osbourn AE. Fungal resistance to plant antibiotics as a mechanism of pathogenesis. Microbiol Mol Biol Rev 1999;63:708-24.
126. Vikram A, Jayaprakasha GK, Jesudhasan PR, Pillai SD, Patil BS. Suppression of bacterial cell-cell signalling, biofilm formation and type III secretion system by citrus flavonoids. J Appl Microbiol 2010;109:515-27.

127. Chevrot R, Rosen R, Haudecoeur E, Cirou A, Shelp BJ, Ron E, et al. GABA controls the level of quorum-sensing signal in Agrobacterium tumefaciens. Proc Natl Acad Sci U S A 2006;103:7460-4.

128. Vandeputte OM, Kiendrebeogo M, Rajaonson S, Diallo B, Mol A, El Jaziri M. Identification of catechin as one of the flavonoids from Combretum albiflorum bark extract that reduces the production of quorum-sensing-controlled virulence factors in Pseudomonas aeruginosa PAO1. Appl Environ Microbiol 2010;76:243-53.

129. Zhao WH, Hu ZQ, Hara Y, Shimamura T. Inhibition by epigallocatechin gallate (EGCg) of conjugative R plasmid transfer in Escherichia coli. J Infect Chemother 2001;7:195-7.

130. Girennavar B, Cepeda ML, Soni KA, Vikram A, Jesudhasan P, Jayaprakasha GK. Grapefruit juice and its furocoumarins inhibits autoinducer signaling and biofilm formation in bacteria. Int J Food Microbiol 2008;125:204-8.

131. Chauhan MK, Malik S. Evaluation of phytochemicals and synergistic interaction between plant extracts and antibiotics for efflux pump inhibitory activity against Salmonella enterica serovar typhimurium strains. Int J Pharm Pharm Sci 2016;8:7-11.

132. Nair R, Chabhadiya R, Chanda S. Marine algae: Screening for a potent antibacterial agent. J Herb Pharmacother 2007;7:73-86.

133. Brackman G, Cos P, Maes L, Nelis HJ, Coenye T. Quorum sensing inhibitors increase the susceptibility of bacterial biofilms to antibiotics in vitro and in vivo. Antimicrob Agents Chemother 2011;55:2655-61.

134. Brackman G, Hillaert U, Van Calenbergh S, Nelis HJ, Coenye T. Use of quorum sensing inhibitors to interfere with biofilm formation and development in Burkholderia multivorans and Burkholderia cenocepacia. Res Microbiol 2009;160:144-51.

135. Yang L, Rybtke MT, Jakobsen TH, Hentzer M, Bjarnsholt $\mathrm{T}$, Givskov M. Computer-aided identification of recognized drugs as Pseudomonas aeruginosa quorum-sensing inhibitors. Antimicrob Agents Chemother 2009;53:2432-43.

136. Warnke PH, Becker ST, Podschun R, Sivananthan S, Springer IN, Russo PA, et al. The battle against multi-resistant strains: Renaissance of antimicrobial essential oils as a promising force to fight hospitalacquired infections. J Craniomaxillofac Surg 2009;37:392-7.

137. Mulyaningsih S, Sporer F, Zimmermann S, Reichling J, Wink M. Synergistic properties of the terpenoids aromadendrene and 1,8-cineole from the essential oil of Eucalyptus globulus against antibiotic-susceptible and antibiotic-resistant pathogens. Phytomedicine 2010;17:1061-6.

138. van Vuuren SF, Suliman S, Viljoen AM. The antimicrobial activity of four commercial essential oils in combination with conventional antimicrobials. Lett Appl Microbiol 2009;48:440-6.

139. Lambert RJ, Skandamis PN, Coote PJ, Nychas GJ. A study of the minimum inhibitory concentration and mode of action of oregano essential oil, thymol and carvacrol. J Appl Microbiol 2001;91:453-62.

140. Iwami Y, Kawarada K, Kojima I, Miyasawa H, Kakuta H, Mayanagi H, et al. Intracellular and extracellular $\mathrm{pHs}$ of Streptococcus mutans after addition of acids: Loading and efflux of a fluorescent $\mathrm{pH}$ indicator in streptococcal cells. Oral Microbiol Immunol 2002;17:239-44.

141. Turgis M, Han J, Caillet S, Lacroix M. Antimicrobial activity of mustard essential oil against Escherichia coli O157:H7 and Salmonella typhi. Food Control 2009;20:1073-9.

142. Niu C, Afre S, Gilbert ES. Subinhibitory concentrations of cinnamaldehyde interfere with quorum sensing. Lett Appl Microbiol 2006;43:489-94. 